\title{
BIRDS OF A FEATHER FLOCK TOGETHER:
}

OWNERSHIP IN CROSS-BORDER ACQUISITIONS BY EMERGING MULTINATIONALS

\author{
Beatriz Domínguez a ${ }^{\text {, * }}$ \\ (bdguez@unizar.es) \\ Universidad de Zaragoza \\ Lucio Fuentelsaz $^{\text {a }}$ \\ (lfuente@unizar.es) \\ Universidad de Zaragoza \\ Elisabet Garrido ${ }^{a}$ \\ (egarrido@unizar.es) \\ Universidad de Zaragoza \\ Minerva González ${ }^{\text {a }}$ \\ (minervag@unizar.es) \\ Universidad de Zaragoza
}

${ }^{a}$ The four authors contributed equally to the paper.

*Corresponding autor. Postal address: Facultad de Empresa y Gestión Pública. Ronda Misericordia, 1. 22001, Huesca (Spain). Telephone number: +34 974239373.

Acknowledgements: We acknowledge financial support from the Spanish Ministry of Economy, Industry and Competitiveness and FEDER (project ECO2017-85451-R), the Regional Government of Aragón (GENERES group, S54_17R) and Universidad de Zaragoza and Ibercaja (JIUZ-2017-SOC-08). 
BIRDS OF A FEATHER FLOCK TOGETHER:

OWNERSHIP IN CROSS-BORDER ACQUISITIONS BY EMERGING MULTINATIONALS

\begin{abstract}
Purpose: Despite prior studies on cross-border acquisitions (CBAs) having analyzed the determinants of ownership strategies, there is still a quest for evidence showing how the differences between home and host market characteristics affect the ownership percentage. Prior studies have acknowledged that entering host countries with greater uncertainty makes multinationals reluctant to acquire high levels of ownership. Nevertheless, emerging multinationals (EMNEs) are usually used to operating under greater levels of uncertainty than multinationals from advanced countries (AMNEs), which can imply different ownership strategies. The purpose of this study is to analyze the ownership percentage acquired by MNEs when designing CBAs in emerging or advanced countries and to determine the extent to which the ownership strategy in emerging countries differs between EMNEs and AMNEs.

Design/methodology/approach: The mobile telecommunications industry is used as a research setting to provide empirical evidence of the interaction effect of the advanced versus emerging nature of host and home countries on the ownership acquired in CBAs.

Findings: The results confirm that both home and host countries' characteristics are relevant in explaining the ownership strategies of MNEs.

Originality/value: The authors contribute to the strategy and IB literature by providing empirical evidence for the recent debate on whether the internationalization strategies followed by EMNEs are similar to the traditional patterns of AMNEs and determining how EMNEs differ from AMNEs in their ownership strategies in emerging countries. Focusing on the mobile telecommunications industry, the authors also contribute by extending the analysis to an international and cross-cultural setting that includes 48 mobile groups from 35 home and 81 host countries.
\end{abstract}

Keywords: ownership; emerging multinationals; emerging markets; cross-border acquisitions; mobile telecommunications industry. 


\section{INTRODUCTION}

Multinational enterprises (MNEs) have substantially increased their contribution to economic activity in the last couple of decades, and currently they generate almost one-third of the world's total production (OECD, 2018). In their internationalization process, MNEs should make two key strategic decisions, namely entry mode and ownership (Xu and Shenkar, 2002). Regarding the former, they can internationalize through a greenfield investment—establishing the new company from scratch—or by performing a cross-border acquisition (CBA) — acquiring an existing company in the new country. The two modes of entry have some advantages and disadvantages (Brouthers and Brouthers, 2000; Slangen and Hennart, 2007). Nevertheless, in the last few years, CBAs have shown stronger growth than greenfield investments (UNCTAD, 2018), encouraging researchers to analyze the determinants of CBAs in greater depth.

When MNEs enter a country through a CBA, the second key decision to make is the percentage of ownership to acquire in the target company (Chari and Chang, 2009; Cuypers et al., 2015; Malhotra and Gaur, 2014). The evidence shows that the CBAs of MNEs vary significantly in respect of the ownership acquired (Chari and Chang, 2009; Chikhouni et al., 2016; Kim et al., 2020; Wang and Larimo, 2020). According to the prior literature, the choice of ownership acquired is determined by factors such as the resource commitment, the expected control by the MNE over the target company or the risks and performance of the acquisition (Anderson and Gatignon, 1986; Delios and Beamish, 1999). The literature rooted in the transaction cost theory (also known as institutional economics) has traditionally suggested that environmental uncertainty increases the difficulty for foreign buyers in seeking, negotiating with and monitoring market transaction partners (Williamson, 1981). In contexts with higher environmental uncertainty, MNEs prefer to acquire lower levels of ownership to gain the flexibility to respond to environmental changes (Li and Li, 2010; Yiu and Makino, 2002). Empirical studies have opened a debate about how the ownership strategy of MNEs varies depending on whether they expand to advanced or to emerging countries, which are characterized by different levels of uncertainty (Liou et al., 2016). ${ }^{[1]}$ Emerging countries feature underdeveloped financial intermediaries and weak securities regulation, which

\footnotetext{
${ }^{1}$ We adopt the classification of the International Monetary Fund (IMF), which distinguishes between advanced markets and emerging and developing economies, following similar previous studies (Liou et al., 2017). In this paper, we use the terms "advanced" and "developed” synonymously. The same applies to the terms "emerging" and "developing." The variables that the IMF takes into account to elaborate this classification are income per capita, export diversification and the degree of integration into the global financial system. For more details, see https://www.imf.org/external/pubs/ft/weo/faq.htm\#q4b.
} 
increase the perceived uncertainty of carrying out business in these countries (Khanna and Palepu, 1997; Zaheer, 1995). As a result, MNEs usually choose a greater ownership percentage when entering advanced countries, where the level of uncertainty tends to be lower than in emerging countries (Delios and Beamish, 1999; Lebedev et al., 2015; Yiu and Makino, 2002).

Prior studies have focused primarily on the institutional conditions of the host country as determinants of uncertainty. Nevertheless, the institutional conditions in the home country are also relevant in explaining the ownership strategy in CBAs (De Beule et al., 2014; Lebedev et al., 2015; Liou et al., 2017). Recent research has suggested that, when expanding abroad, the strategies and performance of MNEs that come from emerging countries—emerging MNEs (EMNEs)—are different from those that come from advanced ones-advanced MNEs (AMNEs) (Cuervo-Cazurra, 2012; De Beule et al., 2014; Guillén and García-Canal, 2009; Luo et al., 2019). EMNEs are used to operating under political uncertainty (Cuervo-Cazurra, 2016), high levels of corruption (Cuervo-Cazurra, 2006) and a lack of transparency in their home countries (Sun et al., 2012). These institutional difficulties provide EMNEs with better knowledge of the circumstances and procedures involved in operating in countries where the quality of institutions is weak, which is known as institutional learning (Cuervo-Cazurra et al., 2018). As a result of this institutional learning, EMNEs develop some resources and capabilities to interact with weak institutions in host countries. Thus, compared with AMNEs, it is expected that EMNEs operate with greater guarantees in uncertain environments, such as emerging countries. We elaborate on this idea and consider that the uncertainty that MNEs perceive in the host country will also depend on the level of development of their home countries. Thus, host country characteristics are relevant in explaining the ownership strategies of MNEs, but the inclusion of home country characteristics is also necessary to comprehend these strategies fully. In spite of this, to our knowledge, prior studies have underexplored the interaction of host and home countries' characteristics in the ownership level decision.

Besides the home and host countries' characteristics, the ownership strategy followed by MNEs can be conditioned by the characteristics of the industry in which CBAs take place. Previous studies have analyzed internationalization strategies in different contexts, such as R\&D-intensive industries (Chari and Chang, 2009; Prashantham and Birkinshaw, 2015; Qian et al., 2018), the hotel industry (Romero-Martínez et al., 2019) or the tire industry (Rose and Ito, 2009). Our research focuses on one regulated industry, the mobile telecommunications industry, which has special features that make it an interesting context in which to analyze the ownership strategies followed by MNEs. In particular, regulated industries are subject to 
greater political risk, which may require firms to make a strong commitment of resources (García-Canal and Guillén, 2008). This might imply that the interaction effect of the home and host countries’ characteristics is highly relevant when determining the ownership strategies of MNEs in regulated industries. We pay attention to this and investigate how host and home countries' characteristics determine the ownership percentage acquired by telecom MNEs.

The aim of this article is twofold. First, we pay attention to host countries' characteristics and analyze the ownership percentage acquired by MNEs when designing CBAs in emerging or in advanced countries. Second, we incorporate the characteristics of the home country and analyze the extent to which the ownership strategy in emerging countries differs between EMNEs and AMNEs. Our findings confirm that both home and host countries' characteristics are relevant in understanding the ownership strategies of MNEs. We show that telecom MNEs tend to acquire lower levels of ownership in emerging countries. Nevertheless, the origin of the MNE significantly moderates this relationship. EMNEs acquire higher levels of ownership in emerging countries than AMNEs.

The contribution of this study is twofold. Firstly, we provide empirical evidence for the recent debate on whether the internationalization strategies followed by EMNEs are similar to the traditional patterns of AMNEs (Guillen and Garcia-Canal, 2009; Luo et al., 2019; Ramamurti, 2012). We shed light on this topic and analyze the extent to which EMNEs differ from AMNEs in their ownership strategies in emerging countries. In doing so, we argue that the integration of home and host countries' characteristics is necessary to comprehend fully the ownership strategies in CBAs. Secondly, our research centers on the global mobile telecommunications industry and includes a wide number of telecom MNEs and many home and host countries. This allows us to expand prior studies by extending the analysis to an international and crosscultural setting. Previous studies that have analyzed the effect of institutional distance on ownership strategies have usually been limited to a few home or host countries (Pinto et al., 2017). This is surprising since many authors have warned against the use of a unique reference point when conducting institutional distance research (Brouthers et al., 2016; van Hoorn and Maseland, 2016). Using a sample that is compounded by a few home or host countries is problematic because it leads to the confluence of institutional distance and institutional profile effects (van Hoorn and Maseland, 2016). We contribute to prior studies by analyzing a sample that is compounded of 35 home countries and 81 host countries.

The remainder of the paper proceeds as follows. First, we present the theoretical framework and the hypotheses of this article. Second, we develop an empirical analysis to test these hypotheses. In particular, 
this section begins with a detailed description of the ownership strategies that are followed by telecom MNEs in CBAs. We pay attention to the developed or emerging nature of the host countries where CBAs take place and, afterwards, we center on the developed or emerging nature of telecom MNEs. This allows us to obtain some interesting findings about the ownership strategies of telecom MNEs. Nevertheless, we take one step further and perform a regression analysis to test our hypotheses. Thus, we present the sample, the variables and the methodology that are used in the second analysis. Finally, we comment on the results of this research and offer a discussion on the main conclusions and future research directions that are derived from our study.

\section{THEORETICAL FRAMEWORK AND HYPOTHESES}

The choice of the initial level of ownership in a CBA when an MNE enters a foreign market is important since it has a clear economic, financial and strategic impact on the acquirer and the target company (Chari and Chang, 2009; Ellis et al., 2018; Pinto et al., 2017). The acquisition of a high level of ownership in the target allows MNEs complete control over operations, facilitating the management functions within the subsidiary and providing access to a higher percentage of the profits. Contrarily, it entails greater risks and costs because of the commitment of resources and the lack of flexibility (Anderson and Gatignon, 1986; Li and Li, 2010; Authors, 2020[2]). By contrast, a lower level of ownership provides access to complementary resources that were not previously available and facilitates risk diversification (Anderson and Gatignon, 1986; Li and Li, 2010; Authors, 2020), but it leads to potential opportunistic costs associated with the post-acquisition integration and to a lack of control.

When MNEs expand into a new host market through CBAs, they often do not have sufficient knowledge of the new context (Chari and Chang, 2009). The environment in the home country may be substantially different, which increases the challenge of understanding the complexities of conducting business in the host country (Mezias, 2002; Zaheer, 1995). As a result of cultural, normative, political and social structures and economic conditions, companies face difficulties that arise from being foreign in the new environment (Johanson and Vahlne, 1977, 2009). Therefore, the selection of the appropriate level of ownership may determine the success and survival of acquiring firms (Contractor et al., 2014; Delios and Beamish, 2001). The previous literature has demonstrated that the level of ownership initially acquired

\footnotetext{
${ }^{2}$ We do not provide the full reference to this forthcoming paper to maintain anonymity in the evaluation process.
} 
depends on factors such as the board composition (Ilhan-Nas et al., 2018), CEO overconfidence (Lai et al., 2017), cultural distance (Kim et al., 2020), home market size (Liou et al., 2015), psychic distance (Chikhouni et al., 2017) and other external factors (see Xie et al., 2017, for a review about the country determinants of M\&As). A mistake in the ownership level may result in high integration costs that may destroy the CBA’s performance (Lahiri et al., 2014; Zhao et al., 2004). As a consequence, MNEs should carefully evaluate the ownership level to acquire when developing a CBA.

We base this research on institutional economics and the institutional view to present two hypotheses on the level of ownership acquired by MNEs in CBAs. First, we use the pro-market view of institutions, which is derived from institutional economics, to explain how the quality of the host country's institutions determines the ownership acquired by MNEs. Second, we rely on the institutional view to explain how the institutional learning acquired in the home country makes EMNEs more likely to acquire a higher level of ownership when conducting CBAs in emerging countries in comparison with AMNEs.

\subsection{The ownership level in CBAs: emerging vs. advanced host countries}

The decision about the percentage of ownership acquired by an MNE when performing a CBA is even more difficult when the CBA takes place in an emerging country characterized by institutional voids that increase the perceived level of uncertainty (Lebedev et al., 2015). Prior research has coined the term "institutional voids" to refer to the absence of market-supporting institutions that are usually requested by foreign investors to develop investments in a new country (Khanna and Palepu, 1997). Emerging economies are characterized by underdeveloped capital and labor markets, in which a lack of financial and other specialized intermediaries makes it more difficult to accomplish key activities for developing activities abroad, such as information searching or negotiating with partners, customers and suppliers (Meyer et al., 2009). Moreover, these markets suffer from a weak legal infrastructure, insufficient protection of property rights and weak judiciary systems to enforce contracts (Contractor et al., 2014). It has also been observed that corruption tends to be higher in emerging markets, so opportunistic behavior of market agents is more likely to occur (Judge et al., 2011).

The institutional environment affects internationalization decisions (Hitt, 2016). In particular, previous studies have shown that confronting higher levels of uncertainty causes MNEs to acquire lower levels of ownership to obtain greater levels of flexibility (Delios and Beamish, 1999; Li and Li, 2010). Less resource commitment will allow them to leave the investment more easily if their expectations are unsatisfied. Additionally, previous studies have suggested that a smaller share of control is preferred when 
there is potential for opportunism of local managers. The reason is that this provides incentives for target firm managers to cooperate in the post-entry period (Chari and Chang, 2009). This cooperation facilitates the transfer of tacit assets, such as market knowledge and relationships with suppliers, the local labor force and governments, from local managers to the acquirer’s managers (Chari and Chang, 2009; Chen and Hennart, 2004; Kogut and Singh, 1988). As Dow et al. (2016, p. 323) posited, "the buyer may prefer to leave a portion of the equity of the firm in hands of the prior management and owners, in order to give them a strong incentive to continue contributing to the success of the firm.” In accordance with these arguments, we suggest that higher levels of uncertainty lead to lower levels of acquired ownership with the aim of preserving flexibility (Delios and Beamish, 1999) and reducing the opportunistic behavior of local managers in the post-entry period (Chari and Chang, 2009). The greater the uncertainty in the host market, the greater the likelihood of taking minority shares instead of acquiring majority percentages (Gerpott and Jakopin, 2008; Liou et al., 2016; Xie et al., 2017). ${ }^{[3]}$

In contrast, when MNEs perform CBAs in advanced countries, the institutional void tends to weaken. Advanced countries usually have strong financial systems that facilitate economic exchanges and strong legal and judiciary regimes that enforce contracts and protect property rights. Additionally, advanced countries usually have formal systems that enable foreign investors to develop their economic activities with lower levels of uncertainty and information asymmetry (Meyer et al., 2009). As formal procedures are explicit and market intermediaries work properly, it is easier for MNEs to obtain information and to negotiate contracts and enforce them. In other words, it is easier to undertake activities in advanced than in emerging countries. Thus, the level of uncertainty is lower in advanced countries, which allows MNEs to make a better assessment of the potential value and costs derived from the CBA, encouraging them to acquire a higher level of ownership. This reasoning leads us to propose our first hypothesis:

Hypothesis 1: The level of ownership acquired is lower when a CBA takes place in an emerging host country than in an advanced host country.

\footnotetext{
${ }^{3}$ This reasoning follows the "default" hypothesis of Anderson and Gatignon (1986, p. 8), which establishes that "a low level of ownership is preferable until proven otherwise." As entering into a new international market entails risk and uncertainty, especially in emerging markets in which institutional voids exist, it reduces the incentive for acquiring firms to enter through wholly owned subsidiaries. However, it should be noted that Anderson and Gatignon (1986) highlighted some factors that reduce the perceived uncertainty in the new country because they allow a better assessment and judgment of local managers' behavior. Among these factors, we emphasize the international experience of the acquirer and the institutional distance between home and host countries. When these factors hold, the incentives to acquire higher levels of ownership increase. As will be explained in Section 3.4, we include several control variables that consider these factors, such as the group international experience, the geographic distance and the cultural distance between the home country of the MNE and the host market in which the CBA takes place.
} 


\subsection{The ownership level in emerging countries: EMNEs vs. AMNEs}

Previous theories on firms' internationalization, including those that are used to explain ownership level decisions, have usually been tested by analyzing the behavior of AMNEs in host developed and emerging countries (Luo et al., 2019). In many industries, the internationalization process of AMNEs started earlier than that of EMNEs. However, some years later, EMNEs appeared and showed an accelerated pace of internationalization. In this context, a recent debate in the international business literature has focused on whether prior theories, primarily applied to AMNEs, can also be used to explain the behavior of EMNEs (Luo and Tung, 2007). While some authors have argued that prior theories also explain EMNEs' behavior, other research has claimed that the initial conditions of EMNEs, their motivation and the pace of their internationalization processes are quite different from those of AMNEs (Guillén and García-Canal, 2009; Liou et al., 2016; Madhok and Keyhani, 2012). As a result, it has been argued that EMNEs have developed different resources and capabilities from AMNEs and differ substantially in their sources of competitive advantage (Cuervo-Cazurra, 2016; Cuervo-Cazurra and Genc, 2008; Ramamurti, 2012).

Compared with AMNEs, EMNEs tend to be smaller, have less advanced technology and fewer sophisticated resources and find it more difficult to access capital markets (Cuervo-Cazurra and Genc, 2008). However, EMNEs tend to develop certain skills and abilities in their home countries that are useful for managing institutionally difficult conditions. Since they have to deal with poorly developed institutions in their home countries, EMNEs acquire specific knowledge that is valuable for operating under adverse institutional conditions. This institutional learning can be highly useful when they decide to enter other emerging countries (Cuervo-Cazurra et al., 2018). In accordance with this idea, previous studies have suggested that EMNEs face political uncertainty in their home countries that allows them to develop capabilities to deal with this type of uncertainty in the future (Cuervo-Cazurra, 2016). The capability acquired by EMNEs' managers to interact with political instability will be useful for these firms to adjust better to political uncertainty and governmental changes when expanding abroad, primarily when entering emerging countries. For instance, Holburn and Zelner (2010) found that MNEs that have developed some capabilities to assess political risk or to manage policy-making processes in their home countries are able to confront political risk better in a new host country. In the same way, managers from EMNEs may face difficult situations in their home countries (Cuervo-Cazurra, 2016) that help them to develop some capabilities to deal with similar conditions in the future. In particular, this institutional learning will result in EMNEs' managers implementing specific organizational policies that will be useful in facing similar situations in a new country. 
Additionally, due to their exposure to changing environments at home, EMNEs develop some improvisational management skills that enable them to react with greater flexibility (Cuervo-Cazurra and Ramamurti, 2016). For instance, Del Sol and Kogan (2007) demonstrated that Chilean companies had acquired knowledge from facing turbulent environments in their home country that helped them to obtain competitive advantages in other Latin American countries during the 1990s. Other studies have shown that, because of their prior experience with bribery, firms that come from countries with high levels of corruption are more likely to expand into other countries where corruption exists (Cuervo-Cazurra, 2006).

All this institutional learning acquired in their home countries could be a source of competitive advantage for EMNEs in their internationalization processes (Martin, 2014). In particular, the resources and capabilities that have been developed as a result of this learning can be used to counteract the adverse conditions of emerging markets (Cuervo-Cazurra, 2016; Cuervo-Cazurra and Genc, 2008; Meyer et al., 2011), making EMNEs more able to operate effectively in countries with high levels of uncertainty (Cuervo-Cazurra et al., 2018). Because EMNEs are accustomed to dealing with high levels of uncertainty at home, they are better positioned to deal with uncertainty abroad (Cuervo-Cazurra et al., 2018). In contrast, AMNEs are used to a properly functioning market system in their home countries and therefore may find it difficult to operate in countries with weak institutions.

As previously mentioned, MNEs decide about the level of ownership that they wish to acquire based on the level of uncertainty perceived in the acquisition process. This explains why MNEs tend to acquire a lower level of ownership when making CBAs in emerging countries (Hypothesis 1). Nevertheless, because of the institutional learning acquired in their home country and the new capabilities developed, EMNEs are better prepared for operating successfully in emerging countries and therefore perceive lower uncertainty when entering such countries. This lower uncertainty makes EMNEs more likely than AMNEs to acquire a higher level of ownership when making CBAs in emerging countries. In other words, the institutional learning of EMNEs serves as a mechanism to reduce the uncertainty perceived when expanding into an emerging country; therefore, the emerging origin of EMNEs positively moderates the relationship between the ownership acquired in CBAs and the emerging nature of the host country. This reasoning leads us to our second hypothesis.

Hypothesis 2: Being an EMNE positively moderates the negative relationship between the level of ownership acquired and the emerging nature of the host country. 


\section{RESEARCH SETTING, SAMPLE, VARIABLES AND METHODS}

\subsection{The mobile telecommunications industry}

Our analyses are undertaken in the mobile telecommunications industry. This industry is highly suitable for the purposes of this study for many reasons. First, it is a very important sector that contributes significantly to the global economy. In 2016, the revenues of the mobile telecommunications industry amounted to US\$3.3 trillion or 4.4 percent of the world GDP (GSMA, 2018). Second, it is an industry in which mobile groups have substantially expanded abroad in the last decades; additionally, CBAs are the most frequent entry mode. The growing number of entries and the preference for CBAs as the mode of entry make this industry highly suitable for analyzing the ownership strategies that MNEs follow when performing CBAs. One of the key reasons for the fast internationalization of telecom firms was the adoption of the Global System for Mobile Communications (GSM) as the standard of digital mobile networks in the 1990s, which allowed the exploitation of economies of scale and learning around the world (Fuentelsaz et al., 2008; Gerpott and Jakopin, 2005). According to GSMA Intelligence (2018), nearly 70 percent of international entries made by telecom MNEs took place from 2000 to 2016. Additionally, 65 percent of the total entries taking place between 2000 and 2016 were performed through CBAs in this industry. The reason is that a greenfield entry of a telecom MNE is only possible when a new license is available in a market. Thus, greenfield investments are limited to certain time windows when license auctions take place (Claussen et al., 2018). For this reason, CBAs are the most frequent entry mode in the mobile telecommunications industry. Third, in this industry, there is wide diversity in terms of the origin of telecom MNEs and the countries that they have entered. This allows us to analyze better the interaction effect between home and host countries’ characteristics. Initially, telecom MNEs came from advanced economies in Europe and the United States and primarily entered other advanced countries. However, nowadays, we find high variability in terms of the economic development of both the home and the host country of mobile groups (Claussen et al., 2018).

\subsection{A descriptive analysis of the ownership strategies in the mobile telecommunications industry}

With regard to the ownership strategy, the evidence shows that the CBAs of mobile groups vary significantly in respect of the ownership acquired (Gerpott and Jakopin, 2008). Previous studies have primarily mentioned the restrictions imposed by the regulation on foreign direct investment (FDI), the stage of telecom liberalization, the reaction of former monopolistic operators and the strategic alliances of 
incumbents as determinants of the ownership percentage acquired by telecom MNEs making CBAs (see Jakopin, 2008, for a review).

However, prior studies have not investigated whether the ownership strategy in the mobile telecommunications industry varies between advanced and emerging host countries and between AMNEs and EMNEs. We offer a descriptive analysis of the ownership strategy followed by telecom multinationals with the aim of identifying the main relationships between the ownership strategies and the emerging nature of the home and host countries of MNEs. In particular, we carry out a descriptive analysis of the 175 CBAs that took place in the industry between 2001 and 2016. The 48 MNEs that performed these CBAs came from 35 home countries and expanded to 81 host countries. ${ }^{\left[{ }^{4}\right.}$ As can be seen in Table I, the average percentage acquired was 66.7 percent. AMNEs made a total of 72 CBAs during this period, accounting for 41 percent of the total. The average ownership acquired by AMNEs was 64.5 percent. EMNEs made 103 CBAs (59 percent of the total), with an average of 66.14 percent ownership. Thus, EMNEs and AMNEs acquired similar levels of ownership. This may suggest that, on average, they follow similar ownership strategies. However, if we delve deeper into the analysis, we can see that the ownership percentage acquired varies depending on the level of host country development. As can be observed in the last column of Table I, the ownership percentage acquired in advanced countries is slightly higher than that in emerging countries (70.0\% vs. 65.7\%). Additionally, significant differences were found when considering the origin of the MNE. While the average ownership percentage acquired by AMNEs was much higher in advanced host countries than in emerging ones (74.2\% vs. 56.4\%), EMNEs acquired higher levels of ownership in emerging countries than in advanced countries (69.6\% vs. 48.4\%).

Insert Table I about here

An additional point arises from Table I that should be highlighted. Whereas AMNEs entered emerging and advanced host countries equally (33 advanced and 39 emerging host countries), EMNEs primarily focused their expansion on emerging economies: only seven out of 103 CBAs took place in advanced countries during the period under analysis. To sum up, Table I allows us to infer two main conclusions: the level of the ownership percentage acquired is, on average, slightly higher in advanced

\footnotetext{
${ }^{4}$ See Appendix A for a detailed list of the host and home countries that are included in the sample.
} 
countries; and EMNEs and AMNEs acquire higher levels of ownership in countries that have a similar level of economic development to their country of origin.

We now take a step further and present a more detailed analysis of the evolution of the percentage acquired by mobile groups from 2001 to 2016, differentiating between their home countries. Table II shows the CBAs carried out by mobile groups from advanced countries, while Table III presents this information for EMNEs. As can be seen in Table II, AMNEs made a total of 72 CBAs. Almost three out of four of the CBAs made by AMNEs (53 out of 72) took place in the first half of our observation window - that is, from 2001 to 2008. During these years, AMNEs entered both advanced and emerging countries, with slight predominance of the latter. With the exception of some years, such as 2009 and 2013, AMNEs acquired higher levels of ownership in advanced countries. In these countries, they acquired, on average, 74.2 percent of operators' equity. In contrast, the mean value of the ownership acquired in emerging countries was 56.4 percent.

Insert Table II and Table III about here

Regarding EMNEs, Table III provides some interesting information about the evolution of CBAs in emerging and advanced host countries. As can be observed in the last column of Table III, EMNEs primarily made their international expansion from 2004 to 2010. Although they started their internationalization process later than AMNEs, EMNEs undertook many CBAs as well. In fact, EMNEs have been involved in an accelerated internationalization process since 2004 and have primarily used CBAs as their entry mode to build faster resources and the capability to compete globally (Bonaglia et al., 2007; Liou et al., 2016; Mathews, 2006). Another interesting point that derives from Table III is that EMNEs tend to acquire a substantially lower ownership percentage when entering advanced countries than when expanding to emerging host countries (48.4\% vs. $70 \%)$.

Besides this, we can obtain interesting findings by paying attention to the number of CBAs and the ownership levels per group. Table IV and Table V provide further information about how many CBAs were made by each mobile group and the ownership that was acquired. Once again, we consider the origin of mobile groups and differentiate between EMNEs and AMNEs. Table IV refers specifically to EMNEs and Table V to AMNEs.

With regard to AMNEs, Orange, Telia and Vodafone, which made eight, seven and seven CBAs, respectively, were the mobile groups with the greatest number of CBAs, as shown in Table IV. Looking at 
where CBAs took place, we find significant differences in the ownership percentage that was acquired by AMNEs. In advanced countries, AMNEs acquired an average of over 50 percent, with the exception of NTT DoCoMo, and the figure was often close to 80 percent. However, the heterogeneity in the ownership percentage acquired by AMNEs was much higher when entering emerging countries. In this case, the percentage was often below 50 percent, with the exception of Orange, Telefónica and Vodafone, which acquired, on average, between 70 percent and 80 percent in emerging countries. The fact that Orange, Telefónica and Vodafone are some of the groups with the highest levels of international experience may explain this result since prior experience can influence firm behavior.

Insert Table IV about here

Regarding EMNEs, Table V shows that seven groups stand out as being primarily responsible for the CBAs made by EMNEs (67 out of 103 acquisitions). These groups are Bharti Airtel (which made 12 CBAs), Zain (11), VimpelCom (11), Etisalat (9), Global Telecom (8), Maroc Telecom (8) and MTN (8). Table $\mathrm{V}$ also shows that almost all the CBAs carried out by EMNEs took place in emerging countries. Furthermore, the few acquisitions that occurred in advanced countries were made by groups that had previously completed acquisitions in emerging countries. ${ }^{[5]}$ On average, the ownership acquired by EMNEs was higher in emerging countries (70.0\%) than in advanced countries (48.4\%). However, three groupsMTN, Oi and VimpelCom—performed CBAs with higher levels of ownership in advanced countries than in emerging ones. MTN and VimpelCom are again two of the groups with the highest international experience of performing CBAs.

Insert Table $\mathrm{V}$ about here

\subsection{Sample, variables and methodology}

The previous section is based on a descriptive analysis that takes into account the behavior of EMNEs and AMNEs when expanding abroad. Although this analysis provides us with an interesting perspective, we now deepen our analysis of the interaction between the levels of development of the home and host countries and its effect on the level of ownership acquired in CBAs to acquire better knowledge.

\footnotetext{
${ }^{5}$ In fact, groups that had previously made CBAs in emerging countries carried them out many times and not just once.
} 
We test our hypotheses using the same sample as in the descriptive analysis-that is, 175 CBAs carried out in 81 host countries by 48 MNEs from 35 home countries in a time frame that covers 2001 to 2016. Our data come from different sources, but the main one is GSMA Intelligence (2018). To obtain our control variables, we use the Heritage Foundation and the World Development Indicators.

\section{Dependent variable}

The dependent variable is the percentage of ownership that an MNE (the acquirer firm) acquires in a subsidiary (the target firm). In line with recent studies, we use a continuous variable that is bounded between 10 percent and 100 percent (Cuypers et al., 2015; Dow et al., 2016; Malhotra and Gaur, 2014). ${ }^{6}$ ]

\section{Independent variables}

Emerging country. We introduce a dummy variable that takes the value of 1 when the country where the CBA takes place is an emerging country and 0 otherwise. Following previous studies, we use the official classification of the International Monetary Fund (IMF) to classify countries as advanced or emerging (De

Beule et al., 2014). ${ }^{[7]}$

Emerging multinational enterprises (EMNEs). To account for the origin of the MNE, we also use a dummy variable that takes the value of 1 when the MNE comes from a country that is classified as an emerging country in accordance with the IMF classification and 0 otherwise.

\section{Control variables}

Similar to previous studies, our model controls for some firm and market characteristics. We control for the subsidiary size, since smaller subsidiaries may need more resources and therefore may be susceptible to being acquired with greater levels of ownership. We measure the subsidiary size as millions of connections.$^{[8]}$ We also control for the previous experience that mobile groups have in internationalizing (group international experience). We measure this variable by counting the number of countries-other than the original one-where the MNE has a presence. Greater international experience is associated with greater knowledge about the internationalization process and therefore with lower perceived uncertainty. The lower the uncertainty, the higher the level of ownership acquired (Chari and Chang, 2009).

\footnotetext{
${ }^{6}$ We follow the guidelines of the International Monetary Fund (IMF) and the Organization for Economic Cooperation and Development (OECD), which consider the existence of FDI when the MNE owns at least 10 percent of the subsidiary equity. Otherwise, MNEs may not exercise effective management control.

${ }^{7}$ This classification is dynamic, which means that some countries, such as Cyprus or Malta, changed their status during the observed period. However, in most of the cases (96.5\%), countries maintained their status of emerging or advanced over the whole period.

${ }^{8}$ Connections make reference to the number of SIM cards (or phone numbers, where SIM cards are not used), excluding cellular M2M, that were registered on the mobile network at the end of the period (GSMA Intelligence, 2018).
} 
With regard to market characteristics, we control for host and home country characteristics. In particular, we include the opening level of host countries (open markets). The Heritage Foundation calculates an index of economic freedom each year. This index measures the economic freedom based on 12 factors, grouped into four broad pillars (rule of law, government size, regulatory efficiency and open markets). Each factor has a value between 0 (lower freedom) and 100 (higher freedom). We calculate this variable as the average of the three factors' value included in the open market pillar (trade, investment and financial freedom), following other studies with similar purposes (Meyer et al., 2009). The resulting measure is between 0 and 100. Higher values of this variable indicate greater openness of the market. Greater opening of the host country facilitates CBAs (Kandogan and Johnson, 2016) and is positively related to the acquired level of ownership. Similar to previous studies, we also control for the size of the host country (host country size) through its population in millions of habitants obtained from the World Development Indicators. Additionally, countries with lower levels of competition are expected to be more attractive for firms to enter. We approach competition through host country concentration, including the Herfindahl-Hirschman index, on a scale from 0 to 10,000. Similarly, we control for the size and the competitiveness level of the home country by including home country concentration and home country size.

Finally, we also include some variables that relate to the home and host countries. In particular, we control for geographical distance since it may cause firms to perceive greater uncertainty (Malhotra and Gaur, 2014). In line with prior studies, we measure this according to the Geobytes database, which gives the kilometers between the capital city of the home country and that of the host country (Malhotra et al., 2009; Slangen and Beugelsdijk, 2010). We also include geographical distance, ${ }^{2}$ because the cost and benefit trade-off of full versus partial ownership varies at different levels of geographical distance (Malhotra and Gaur, 2014). In addition, we control for cultural distance, because previous studies have suggested that it increases uncertainty and therefore affects the ownership level acquired (Chari and Chang, 2009; Malhotra et al., 2011). Foreign firms will seek to participate less in the local companies of culturally distant countries (Chari and Chang, 2009). We measure cultural distance using a binary variable that takes the value of 1 when there has been a colony-colonizing relationship (or vice versa) between the home and the host country at any time in the past and 0 otherwise (Albino-Pimentel et al., 2018). Finally, we include time effects with dummy variables. 


\section{Descriptive statistics}

Table VI shows the descriptive statistics of our sample. The mean value of ownership is 66.7 percent, with a standard deviation of 32.8 percent. In accordance with our measure, the minimum ownership that mobile groups acquired in the observed period was 12 percent and the maximum was 100 percent. Regarding our independent variables, emerging country has a mean value of 0.8 , with a standard deviation of 0.4. This means that the CBAs that are included in our sample took place more often in emerging countries than in advanced ones. Similarly, the mean value of EMNEs is 0.6, which indicates greater prevalence of CBAs made by EMNEs over those carried out by AMNEs. However, the standard deviation of this variable is 0.5 , which indicates high variability regarding the home country of companies involved in CBAs. EMNEs such as Bharti Airtel and Zain carried out a high number of acquisitions in comparison with other groups, such as NMTC. Similarly, AMNEs such as Orange made eight acquisitions, while other companies, such as the Vivendi Group, made only one in the whole period. Regarding the control variables, we note that, on average, the subsidiary size is 4.3 million connections. However, the high standard deviation (8.7) reveals important differences between firms, which are reflected in the maximum (51) and minimum (0.01) values of this variable. MNEs also show great differences in their levels of internationalization, as is shown by the high value of the standard deviation of group international experience. On average, mobile groups expanded to 12 countries. Some groups, such as Softbank, only expanded to one foreign country, while others, such as Orange, entered more than 40 countries.

Regarding the market characteristics, home and host countries show similar values for the competitiveness level. In particular, the mean value of host country concentration is 4,408 and the mean value of home country concentration is 3,974. The two also have similar standard deviations - 1,547 and 1,922, respectively. Nevertheless, this does not occur when we compare the size of the home and host countries. Home countries tend to be bigger than host countries. While the mean value of host country size is 42.8 million habitants, home country size has a mean value of 137.2 million habitants. Home countries also show greater variability in their size, as is shown by the value of the standard deviation. In addition, the mean value of open markets is 56.3, with a maximum of 90 and a minimum value of 13.3. Finally, we can observe that home and host countries, on average, face a distance of 3.8 thousand kilometers, as is shown by the mean value of geographical distance. Nevertheless, this variable shows a high standard deviation-2.92 — which indicates great variability in the distance between home and host countries. Moreover, home and host countries tend to be culturally different, as can be seen in the mean value of 
cultural distance, which is 0.2 . This value indicates that most of the home and host countries in our sample do not have a previous colony-colonizing relationship.

Insert Table VI about here

Table VII shows the correlations between the variables that are included in our analysis. Generally speaking, the variables do not show very high correlations. Multicollinearity does not pose a problem. We carried out a test for potential multicollinearity before estimating the regression model and found that the variance inflation factor in our models was below 4, far below the threshold of 10 (Kutner et al., 2005). Emerging country is negatively correlated with our dependent variable, while EMNEs are positively associated with it. One of the highest correlations is found between host country size and subsidiary size (0.52). This is because subsidiaries with higher levels of mobile connections are found in the most populated host countries (e.g. Bangladesh, Indonesia and the United States). Similarly, home country size and home country concentration present a correlation of -0.42 . This may be explained by the fact that bigger countries tend to attract more firms (Nachum et al., 2008). The greater the number of competitors in the home market, the lower the probability of having concentrated home countries. Finally, emerging country shows a correlation of -0.42 with open markets. Emerging countries are often closer in terms of the ease of entering them than advanced countries.

Insert Table VII about here

\section{Methodology}

The dependent variable is a limited variable subject to an upper (100\%) and a lower (10\%) boundary. For limited dependent variables, a classic ordinary least squares regression model will give biased and inconsistent estimates (Maddala, 1983). In this situation, a Tobit regression analysis is recommended (Greene, 1993). Indeed, Tobit estimation has been performed in prior studies with an identical dependent variable (Chari and Chang, 2009; Cuypers et al., 2015; Dow et al., 2016; Malhotra and Gaur, 2014; Pan et al., 2014).

\section{RESULTS}

Table VIII provides the results of our Tobit estimations (Models 1 to 5). Model 1 only considers the influence of the control variables in the ownership acquired by MNEs. Model 2 introduces the effect that CBAs in an emerging country have on the dependent variable, to test Hypothesis 1 . Model 3 introduces the 
variable EMNEs to the baseline model and Model 4 incorporates the direct effect of both emerging country and EMNEs. Finally, Model 5 introduces the interaction effect between emerging country and EMNEs to test Hypothesis 2. The likelihood ratio tests are presented at the bottom of Table VIII. They show that Model 5 is the model that best fits our data; thus, we employ it to comment our results.

Insert Table VIII about here

Hypothesis 1 stated that the emerging nature of the host country negatively influences the percentage that MNEs acquire in the subsidiary. Model 5 shows that emerging country has a negative and significant effect on ownership $(\beta=-35.114 ; \mathrm{p}<0.01)$. This means that CBAs in emerging countries are carried out with lower levels of ownership, giving support to Hypothesis 1. MNEs tend to acquire higher levels of ownership in subsidiaries that are located in advanced countries.

However, it is not only the emerging nature of the host country that is important in the choice of ownership acquired, but also the origin of the MNE. Hypothesis 2 posited that MNEs that come from emerging countries acquire higher levels of ownership in emerging countries than AMNEs. Model 5 shows that the interaction term between emerging country and EMNEs is positive and statistically significant $(\beta=44.004 ; \mathrm{p}<0.05)$. Being an EMNE positively moderates the negative impact that making a CBA in an emerging country has on the percentage of ownership acquired. EMNEs opt for a greater ownership percentage than AMNEs when making CBAs in emerging countries. This is consistent with Hypothesis 2 and we cannot therefore reject it.

Figure I depicts this moderating effect by showing two lines. The solid line refers to AMNEs and the dotted line to EMNEs. The former has a negative slope, which means that AMNEs acquire lower ownership percentages in emerging countries than in advanced ones. The opposite trend is found in the case of EMNEs. The positive slope of the dotted line means that EMNEs opt for greater levels of ownership in emerging countries than in advanced countries. This confirms our premise that the origin of the MNE plays a significant role in understanding the relationship between the level of ownership acquired in a CBA and the level of development of the host country where the CBA takes place.

Insert Figure I about here

\section{DISCUSSION AND IMPLICATIONS}


This research has analyzed the entry by MNEs in the mobile telecommunications industry when performing CBAs. More precisely, we have observed that AMNEs and EMNEs behave differently when deciding on the ownership to acquire when entering a foreign country. Prior studies have suggested that the characteristics of the host country significantly determine the level of ownership acquired in a subsidiary. Our premise is that it is not only the host country characteristics that are relevant but also the characteristics of the home country. The latter define the conditions under which MNEs are accustomed to operating and therefore influence their perception of the host country characteristics. Following recent studies, we noted that emerging and advanced countries show great differences in terms of their market characteristics. Thus, we differentiated home and host countries and distinguished between EMNEs and AMNEs. This classification led us to address two research questions.

Firstly, we analyzed how the emerging or advanced nature of the host country determines the level of ownership acquired by MNEs when making CBAs. Our results show that MNEs acquire higher levels of subsidiaries' ownership when CBAs take place in advanced countries. Emerging countries are characterized by institutional voids that cause MNEs to perceive greater uncertainty surrounding CBAs. Due to this, they prefer to acquire a lower percentage of ownership to be able to leave the investment more easily if their expectations are unsatisfied. Moreover, it allows MNEs to maintain local investors that facilitate their introduction into the informal business network of the emerging country. Our results expand prior studies and confirm that the level of development of the host country is highly relevant to explaining the percentage of ownership acquired by MNEs in regulated industries.

Secondly, we investigated whether being an EMNE alters the relationship between the development of the host country and the level of ownership acquired in CBAs. AMNEs and EMNEs behave differently when making CBAs since they are accustomed to different market conditions in their home countries. In particular, we posited that EMNEs acquire higher levels of ownership than AMNEs when making CBAs in emerging countries. Our results confirm this assumption. EMNEs are accustomed to operating under weaker market institutions in their home countries (Cuervo-Cazurra and Genc, 2008), so, in comparison with AMNEs, they perceive lower uncertainty when making CBAs in other emerging countries. Advanced countries usually have stronger market systems that facilitate the development of economic activities. Thus, AMNEs trust in the market mechanisms that support their activities and perceive great uncertainty when these conditions do not exist. This explains why they perceive emerging countries as riskier host countries than EMNEs do. In contrast, EMNEs have a different starting point and know how to operate under weaker 
market mechanisms. Thus, they do not perceive as much uncertainty as AMNEs when making CBAs in other emerging countries and are willing to acquire higher levels of ownership. Our results confirm that MNEs in regulated industries use their skills in dealing with governments and regulators when expanding abroad (García-Canal and Guillén, 2008). EMNEs are likely to acquire greater levels of ownership because they are more confident about dealing with the uncertainty of the host country than AMNEs.

Besides these differences in the internationalization behavior of EMNEs and AMNEs, our research suggests that the prior theories that have been used to explain the internationalization patterns of AMNEs can also be applied to explain the behavior of EMNEs. We thus shed light on the debate on this issue in the international business literature (Luo and Tung, 2007). We observe that both AMNEs and EMNEs are more likely to expand into countries that are institutionally similar to their home country. The explanation for this is that the institutional learning acquired in the home country plays a significant role in the internationalization process of MNEs. Broadly speaking, AMNEs are present in a greater number of advanced host countries than emerging host countries, while EMNEs have expanded more into emerging host countries than advanced host countries. Additionally, our analysis indicates that the institutional learning developed in their home country is especially useful when EMNEs expand into countries where the rules of the game are relatively similar, conferring on them greater confidence that, in turn, leads them to acquire a larger share of the target company.

Our study may be of interest to target firms’ managers and public policy makers. From a managerial point of view, this study shows that the level of development of the country where the target company is located and the level of development of the country of the acquirer will determine the percentage of ownership that MNEs will acquire. The target company may anticipate which MNEs are more likely to acquire higher levels of equity based on their location. When the target company is located in an emerging country, the likelihood of being majority owned by an MNE that comes from an emerging country is greater. As EMNEs have a better understanding of how to counteract institutional voids in emerging countries as a consequence of their institutional learning, managers of AMNEs can find a valuable mechanism for entering emerging markets in the development of strategic alliances with EMNEs. From the point of view of policy makers, this study shows that their decision about how much to intercede in the functioning system of the market will determine the level of ownership that MNEs are likely to acquire when making a CBA. In this vein, governments from emerging countries that are interested in attracting investment from advanced economies should try to reduce the institutional voids that foreign investors perceive. For 
instance, policy makers should try to improve the system of property rights protection and promote mechanisms to facilitate the introduction of foreign investors into the informal business network (e.g., trade associations and conventions). This improvement in the rules of the game is less important when the interest of the governments of emerging countries lies in attracting investments from companies based in other emerging countries.

Our study has contributed to the literature regarding ownership decisions in CBAs through the incorporation of the role of home country characteristics into the analysis of MNEs' strategic decisions. Nevertheless, some issues remain open and deserve further attention in future research. First, our study distinguishes between emerging and advanced countries according to the official classification of the International Monetary Fund (IMF). However, there are important differences between the countries included in each of these two groups, so a finer-grained analysis of the different economies would improve our study. A second future line of research concerns the paper's treatment of institutions. As CuervoCazurra et al. (2019, p. 621) suggested, "we still do not understand well how the various dimensions of institutions interact with each other and the influence that such interactions have on firm behavior.” For this reason, future analysis should consider how more specific dimensions of the formal and informal institutional environment (in both advanced and emerging markets) interact in explaining MNEs' strategy and performance. In particular, one variable that may deserve further attention is the cultural distance between home and host countries. We approach it through a dummy variable based on the existence of a past colony-colonizing relationship (or vice versa) between the home and the host country (AlbinoPimentel et al., 2018). However, alternative variables have been used in the literature, such as the Kogut and Singh index (1988) based on Hofstede or GLOBE measures. It was not possible for us to include these alternative variables because they would significantly reduce our emerging-market sample, but this constitutes a clear avenue for future studies.

Our research is not exempt from limitations. Firstly, we differentiate between emerging and advanced host and home countries by using the IMF official classification. Even though this classification has been used in prior research with similar purposes, we cannot overlook the possibility that countries that are classified into the same group can differ substantially. In fact, when looking at the evolution of countries' development over time, it is apparent that some changed their status during the observed period. This means that those emerging (advanced) countries that are closer to the threshold may be more similar to advanced (emerging) countries than to other countries in the same category. Future research may take 
care of this issue by making more accurate classifications of countries. Secondly, we control for prior experience in making CBAs. However, we do not differentiate whether this experience took place in advanced or emerging countries. AMNEs that have made many CBAs in emerging countries may have acquired enough knowledge about the functioning of these countries and therefore may perceive less uncertainty than other AMNEs without such experience.

To conclude, it is important to note that this study contributes to the prior literature in two ways. Firstly, we show that telecom MNEs face institutional voids in emerging markets that make them acquire higher levels of ownership in advanced countries than in emerging countries. Secondly, our results contribute to the literature by confirming that EMNEs and AMNEs behave differently when expanding abroad because of their different perceptions of uncertainty derived from institutional voids in emerging markets. While EMNEs are used to counteracting institutional voids in their home countries, AMNEs find investments in emerging countries to be risky ventures. Norms and regulations are usually less developed in these countries, which makes business more difficult to conduct. This often leads to an increase in the perceived uncertainty surrounding CBAs. However, EMNEs feel much more comfortable than AMNEs when making CBAs in emerging countries, so they tend to acquire higher levels of ownership than AMNEs in these countries.

\section{REFERENCES}

Albino-Pimentel, J., Dussauge, P., \& Shaver, J. M. (2018). Firm non-market capabilities and the effect of supranational institutional safeguards on the location choice of international investments. Strategic Management Journal, 39(10), 2770-2793.

Anderson, E., and Gatignon, H. (1986). Modes of foreign entry: A transaction cost analysis and propositions. Journal of International Business Studies, 17(3), 1-26.

Bonaglia, F., Goldstein, A. and Mathews, J.A. (2007). Accelerated internationalization by emerging markets' multinationals: The case of the white goods sector. Journal of World Business, 42(4), 369383.

Brouthers, K.D., and Brouthers, L.E. (2000). Acquisition or greenfield start-up? institutional, cultural and transaction cost influences. Strategic Management Journal, 21(1), 89-97.

Brouthers, L. E., Marshall, V. B., \& Keig, D. L. (2016). Solving the single-country sample problem in cultural distance studies. Journal of International Business Studies, 47(4), 471-479. 
Chari, M. D., and Chang, K. (2009). Determinants of the share of equity sought in cross-border acquisitions. Journal of International Business Studies, 40(8), 1277-1297.

Chen, S. F. S., \& Hennart, J. F. (2004). A hostage theory of joint ventures: why do Japanese investors choose partial over full acquisitions to enter the United States?. Journal of Business Research, 57(10), 1126-1134.

Chikhouni, A., Edwards, G., \& Farashahi, M. (2017). Psychic distance and ownership in acquisitions: Direction matters. Journal of International Management, 23(1), 32-42.

Claussen, J., Köhler, R., and Kretschmer, T. (2018). Target choice and unique synergies in global mobile telephony: A dyadic approach. Industrial and Corporate Change, 27(2), 371-386.

Contractor, F. J., Lahiri, S., Elango, B., and Kundu, S. K. (2014). Institutional, cultural and industry related determinants of ownership choices in emerging market FDI acquisitions. International Business Review, 23(5), 931-941.

Cuervo-Cazurra, A. (2011). Global strategy and global business environment: The direct and indirect influences of the home country on a firm's global strategy. Global Strategy Journal, 1(3-4), 382-386.

Cuervo-Cazurra, A. (2006). Who cares about corruption?. Journal of International Business Studies, 37(6), 807-822.

Cuervo-Cazurra, A. (2012). Extending theory by analyzing developing country multinational companies: Solving the Goldilocks debate. Global Strategy Journal, 2(3), 153-167.

Cuervo-Cazurra, A. (2016). Multilatinas as sources of new research insights: The learning and escape drivers of international expansion. Journal of Business Research, 69(6), 1963-1972.

Cuervo-Cazurra, A., Gaur, A., and Singh, D. (2019). Pro-market institutions and global strategy: The pendulum of pro-market reforms and reversals. Journal of International Business Studies, 50(4), 598632.

Cuervo-Cazurra, A., and Genc, M. (2008). Transforming disadvantages into advantages: Developingcountry MNEs in the least developed countries. Journal of International Business Studies, 39, 957979.

Cuervo-Cazurra, A., Luo, Y., Ramamurti, R., \& Ang, S. H. (2018). Impact of the Home Country on Internationalization. Journal of World Business, 53(5), 593-604.

Cuervo-Cazurra, A., \& Ramamurti, R. (2016). Home Country Underdevelopment and Internationalization: Innovation-Based and Escape-Based Internationalization. Competitiveness Review, 27(3), 217-230. 
Cuypers, I. R., Ertug, G., and Hennart, J. F. (2015). The effects of linguistic distance and lingua franca proficiency on the stake taken by acquirers in cross-border acquisitions. Journal of International Business Studies, 46(4), 429-442.

De Beule, F., Elia, S., and Piscitello, L. (2014). Entry and access to competencies abroad: Emerging market firms versus advanced market firms. Journal of International Management, 20, 137-152.

Del Sol, P., \& Kogan, J. (2007). Regional competitive advantage based on pioneering economic reforms: The case of Chilean FDI. Journal of International Business Studies, 38(6), 901-927.

Delios, A., and Beamish, P. W. (1999). Ownership strategy of Japanese firms: Transactional, institutional, and experience influences. Strategic Management Journal, 20(10), 915-933.

Delios, A., and Beamish, P. W. (2001). Survival and profitability: The roles of experience and intangible assets in foreign subsidiary performance. Academy of Management Journal, 44(5), 1028-1038.

Dow, D., Cuypers, I. R., and Ertug, G. (2016). The effects of within-country linguistic and religious diversity on foreign acquisitions. Journal of International Business Studies, 47(3), 319-346.

Ellis, K. M., Lamont, B. T., Holmes Jr, R. M., Ro, S., Faifman, L., DeGhetto, K., and Parola, H. (2018). Institutional determinants of ownership positions of foreign acquirers in Africa. Global Strategy Journal, 8(2), 242-274.

Fuentelsaz, L., Maícas, J. P., and Polo, Y. (2008). The evolution of mobile communications in Europe: The transition from the second to the third generation. Telecommunications Policy, 32(6), 436-449.

García-Canal, E., and Guillén, M.F. (2008). Risk and the strategy of foreign location choice in regulated industries. Strategic Management Journal, 29 (10), 1097-1115.

Gerpott, T. J., and Jakopin, N. M. (2005). The degree of internationalization and the financial performance of European mobile networks operators. Telecommunications Policy, 29(8), 625-661.

Gerpott, T. J., and Jakopin, N. M. (2008). Determinants of mobile network operators' choice of crossborder entry modes. International Journal of Mobile Communications, 6(2), 177-198.

Greene, W. H. (1993). Econometric analysis (2nd ed.). New York: Macmillan.

GSMA Intelligence. (2018). GSMA intelligence dataset. Retrieved from www.gsma intelligence.com

Guillén, M. F., and García-Canal, E. (2009). The American model of the multinational firm and the 'new' multinationals from emerging economies. Academy of Management Perspectives, 23(2), 23-35.

Hitt, M. A. (2016). International strategy and institutional environments. Cross Cultural \& Strategic Management, 23(2), 206-215. 
Ilhan-Nas, T., Okan, T., Tatoglu, E., Demirbag, M., Wood, G., \& Glaister, K. W. (2018). Board composition, family ownership, institutional distance and the foreign equity ownership strategies of Turkish MNEs. Journal of World Business, 53(6), 862-879.

International Monetary Fund (2018). Official classification of advanced economies and emerging and developing economies. Retrieved from https:/www.imf.org/external/pubs/ft/weo/faq.htm\#q4b

Jakopin, N. M. (2008). Internationalisation in the telecommunications services industry: Literature review and research agenda. Telecommunications Policy, 32(8), 531-544.

Johanson, J., \& Vahlne, J. E. (1977). The internationalization process of the firm-a model of knowledge development and increasing foreign market commitments. Journal of International Business Studies, 8(1), 23-32.

Johanson, J., and Vahlne, J. E. (2009). The Uppsala internationalization process model revisited: From liability of foreignness to liability of outsidership. Journal of International Business Studies, 40(9), 1411-1431.

Judge, W. Q., McNatt, D. B., and Xu, W. (2011). The antecedents and effects of national corruption: A meta-analysis. Journal of World Business, 46(1), 93-103.

Kandogan, Y., and Johnson, S. D. (2016). Role of economic and political freedom in the emergence of global middle class. International Business Review, 25(3), 711-725.

Khanna, T., and Palepu, K. (1997). Why focused strategies may be wrong for emerging markets. Harvard Business Review, 75(4), 3-10.

Kim, H. G., Gaur, A. S., \& Mukherjee, D. (2020). Added cultural distance and ownership in cross-border acquisitions. Cross-Cultural \& Strategic Management, in press.

Kogut, B., and Singh, H. (1988). The effect of national culture on the choice of entry mode. Journal of International Business Studies, 19(3), 411-432.

Kutner, M.H., Nachtsheim, C.J., Neter, J., and Li, W. (2005). Applied Linear Statistical Models. 5th ed. Boston: McGraw-Hill Irwin.

Lahiri, S., Elango, B., and Kundu, S. K. (2014). Cross-border acquisition in services: Comparing ownership choice of developed and emerging economy MNEs in India. Journal of World Business, 49(3), 409420.

Lai, J. H., Lin, W. C., \& Chen, L. Y. (2017). The influence of CEO overconfidence on ownership choice in foreign market entry decisions. International Business Review, 26(4), 774-785. 
Lebedev, S., Peng, M. W., Xie, E., and Stevens, C. E. (2015). Mergers and acquisitions in and out of emerging economies. Journal of World Business, 50(4), 651-662.

Li, J., \& Li, Y. (2010). Flexibility versus commitment: MNEs’ ownership strategy in China. Journal of International Business Studies, 41(9), 1550-1571.

Liou, R.-S., Chen-Ho Chao, M., and Yang, M. (2016). Emerging economies and institutional quality: Assessing the differential effects of institutional distances on ownership strategy. Journal of World Business, 51(4), 600-611.

Liou, R., Lee, K., \& Miller, S. (2017). Institutional impacts on ownership decisions by emerging and advanced market MNCs. Cross Cultural \& Strategic Management, 24(3), 454-481.

Luo, Y., and Tung, R. L. (2007). International expansion of emerging market enterprises: A springboard perspective. Journal of International Business Studies, 38(4), 481-498.

Luo, Y., Zhang, H., \& Bu, J. (2019). Developed country MNEs investing in developing economies: Progress and prospect. Journal of International Business Studies, 50(4), 633-667.

Maddala, G. S. (1983). Limited-dependent and qualitative variables in econometrics (No. 3). Cambridge University Press.

Madhok, A., \& Keyhani, M. (2012). Acquisitions as entrepreneurship: Asymmetries, opportunities, and the internationalization of multinationals from emerging economies. Global Strategy Journal, 2(1), 2640.

Malhotra, S., and Gaur, A. S. (2014). Spatial geography and control in foreign acquisitions. Journal of International Business Studies, 45(2), 191-210.

Malhotra, S., Sivakumar, K., and Zhu, P. (2009). Distance factors and target market selection: the moderating effect of market potential. International Marketing Review, 26(6), 651-673.

Malhotra, S., Sivakumar, K., \& Zhu, P. (2011). Curvilinear relationship between cultural distance and equity participation: An empirical analysis of cross-border acquisitions. Journal of International Management, 17(4), 316-332.

Martin, X. (2014). Institutional advantage. Global Strategy Journal, 4(1), 55-69.

Mathews, J.A. (2006). Dragon multinationals: New players in $21^{\text {st }}$ century globalization. Asia Pacific Journal of Management, 23(1), 5-27.

Meyer, K. E., Estrin, S., Bhaumik, S. K., and Peng, M. W. (2009). Institutions, resources, and entry strategies in emerging economies. Strategic Management Journal, 30(1), 61-80. 
Meyer, K. E., Mudambi, R., and Narula, R. (2011). Multinational enterprises and local contexts: The opportunities and challenges of multiple embeddedness. Journal of Management Studies, 48(2), 235252.

Mezias, J. M. (2002). How to identify liabilities of foreignness and assess their effects on multinational corporations. Journal of International Management, 8(3), 265-282.

Nachum, L., Zaheer, S. and Gross, S. (2008). Does it matter where countries are? Proximity to knowledge, markets and resources, and MNE location choices. Management Science, 54(7), 1252-1265.

OECD. (2018). Multinational enterprises in the global economy. Retrieved from https://www.oecd.org/industry/ind/MNEs-in-the-global-economy-policy-note.pdf

Pan, Y., Teng, L., Supapol, A. B., Lu, X., Huang, D., and Wang, Z. (2014). Firms’ FDI ownership: The influence of government ownership and legislative connections. Journal of International Business Studies, 45(8), 1029-1043.

Pinto, C. F., Ferreira, M. P., Falaster, C., Fleury, M. T. L., \& Fleury, A. (2017). Ownership in cross-border acquisitions and the role of government support. Journal of World Business, 52(4), 533-545.

Prashantham, S., and Birkinshaw, J. (2015). Choose your friends carefully: Home-country ties and new venture internationalization. Management International Review, 55(2), 207-234.

Qian, G., Li, L., and Qian, Z. (2018). Interactions Among Factors Driving and Inhibiting the Early Internationalization of Small, Young Technology Enterprises. Management International Review, 58(2), 251-280.

Ramamurti, R. (2012). What is really different about emerging market multinationals? Global Strategy Journal, 2(1), 41-47.

Romero-Martínez, A. M., García-Muiña, F. E., Chidlow, A., \& Larimo, J. (2019). Formal and Informal Institutional Differences Between Home and Host Country and Location Choice: Evidence from the Spanish Hotel Industry. Management International Review, 59(1), 41-65.

Rose, E. L., and Ito, K. (2009). Past interactions and new foreign direct investment location decisions. Management International Review, 49(5), 641.

Slangen, A. H., and Beugelsdijk, S. (2010). The impact of institutional hazards on foreign multinational activity: A contingency perspective. Journal of International Business Studies, 41(6), 980-995.

Slangen, A., and Hennart, J. F. (2007). Greenfield or acquisition entry: A review of the empirical foreign establishment mode literature. Journal of International Management, 13(4), 403-429. 
Sun, S. L., Peng, M. W., Ren, B., \& Yan, D. (2012). A comparative ownership advantage framework for cross-border M\&As: The rise of Chinese and Indian MNEs. Journal of World Business, 47(1), 4-16.

UNCTAD (2018). World Investment Report: Investments and new industrial policies. United Nations Publications, Geneva.

van Hoorn, A., \& Maseland, R. (2016). How institutions matter for international business: Institutional distance effects vs institutional profile effects. Journal of International Business Studies, 47(3), 374381.

Wang, Y., \& Larimo, J. (2020). Survival of full versus partial acquisitions: The moderating role of firm’s internationalization experience, cultural distance, and host country context characteristics. International Business Review, 29(1), 101605.

Williamson, O. E. (1981). The economics of organization: The transaction cost approach. American Journal of Sociology, 87(3), 548-577.

Xie, E., Reddy, K. S., \& Liang, J. (2017). Country-specific determinants of cross-border mergers and acquisitions: A comprehensive review and future research directions. Journal of World Business, 52(2), 127-183.

Xu, D., and Shenkar, O. (2002). Note: Institutional distance and the multinational enterprise. Academy of Management Review, 27(4), 608-618.

Yiu, D., and Makino, S. (2002). The choice between joint venture and wholly owned subsidiary: An institutional perspective. Organization Science, 13(6), 667-683.

Zaheer, S. (1995). Overcoming the liability of foreignness. Academy of Management Journal, 38(2), 341363.

Zhao, H., Luo, Y., and Suh, T. (2004). Transaction cost determinants and ownership-based entry mode choice: A meta-analytical review. Journal of International Business Studies, 35(6), 524-544. 
Table I. The ownership acquired depending on the level of development of the host and the home countries

\begin{tabular}{|c|c|c|c|c|}
\hline & AMNE & EMNE & Total & \\
\hline $\begin{array}{c}\text { Advanced host } \\
\text { country }\end{array}$ & 74.2 & 48.4 & 70.0 & Average percentage acquired \\
\hline $\begin{array}{c}\text { Emerging host } \\
\text { country }\end{array}$ & 33 & 7 & 40 & Number of CBAs \\
\hline Total & 36.4 & 70.0 & 65.8 & Average percentage acquired \\
\hline & 64.5 & 96 & 135 & Number of CBAs \\
\hline & $\mathbf{7 2}$ & $\mathbf{1 0 3}$ & $\mathbf{1 7 5}$ & Number of CBAs \\
\hline
\end{tabular}

Table II. AMNEs' acquisitions by year

\begin{tabular}{|c|c|c|c|c|c|}
\hline Year & $\begin{array}{c}\text { Number of } \\
\text { acquisitions in } \\
\text { advanced host } \\
\text { countries }\end{array}$ & $\begin{array}{c}\text { Average } \\
\text { percentage } \\
\text { acquired }\end{array}$ & $\begin{array}{c}\text { Number of } \\
\text { acquisitions in } \\
\text { emerging host } \\
\text { countries }\end{array}$ & $\begin{array}{c}\text { Average } \\
\text { percentage } \\
\text { acquired }\end{array}$ & $\begin{array}{l}\text { Total number } \\
\text { of acquisitions }\end{array}$ \\
\hline 2001 & 6 & 48.4 & 7 & 52.6 & 13 \\
\hline 2002 & 4 & 100 & 2 & 55.1 & 6 \\
\hline 2003 & 0 & - & 2 & 30.2 & 2 \\
\hline 2004 & 0 & - & 3 & 100 & 3 \\
\hline 2005 & 3 & 50.8 & 3 & 31 & 6 \\
\hline 2006 & 5 & 99.9 & 4 & 74.5 & 9 \\
\hline 2007 & 2 & 95 & 8 & 42.8 & 10 \\
\hline 2008 & 1 & 100 & 3 & 56.9 & 4 \\
\hline 2009 & 5 & 73.4 & 1 & 100 & 6 \\
\hline 2010 & 2 & 75 & 2 & 45.5 & 4 \\
\hline 2011 & 0 & - & 2 & 59.5 & 2 \\
\hline 2012 & 0 & - & 0 & - & 0 \\
\hline 2013 & 2 & 50.1 & 1 & 100 & 3 \\
\hline 2014 & 0 & - & 0 & - & 0 \\
\hline 2015 & 2 & 100 & 1 & 45 & 3 \\
\hline 2016 & 1 & 12 & 0 & - & 1 \\
\hline Total & 33 & 74.2 & 39 & 56.4 & 72 \\
\hline
\end{tabular}

Table III. EMNEs' acquisitions by year

\begin{tabular}{|c|c|c|c|c|c|}
\hline Year & $\begin{array}{l}\text { Number of } \\
\text { acquisitions in } \\
\text { advanced host } \\
\text { countries }\end{array}$ & $\begin{array}{c}\text { Average } \\
\text { percentage } \\
\text { acquired }\end{array}$ & $\begin{array}{c}\text { Number of } \\
\text { acquisitions in } \\
\text { emerging host } \\
\text { countries }\end{array}$ & $\begin{array}{c}\text { Average } \\
\text { percentage } \\
\text { acquired }\end{array}$ & $\begin{array}{l}\text { Total number } \\
\text { of acquisitions }\end{array}$ \\
\hline 2001 & 0 & - & 0 & - & 0 \\
\hline 2002 & 0 & - & 2 & 72.8 & 2 \\
\hline 2003 & 0 & - & 3 & 78.5 & 3 \\
\hline 2004 & 1 & 100 & 10 & 82.5 & 11 \\
\hline 2005 & 2 & 13.2 & 24 & 68.1 & 26 \\
\hline 2006 & 0 & - & 10 & 72 & 10 \\
\hline 2007 & 1 & 12.3 & 7 & 40.7 & 8 \\
\hline 2008 & 0 & - & 7 & 74.3 & 7 \\
\hline 2009 & 0 & - & 3 & 71.8 & 3 \\
\hline 2010 & 0 & - & 13 & 86.8 & 13 \\
\hline 2011 & 1 & 100 & 3 & 43.6 & 4 \\
\hline 2012 & 0 & - & 1 & 100 & 1 \\
\hline 2013 & 0 & - & 0 & - & 0 \\
\hline 2014 & 1 & 100 & 4 & 42.4 & 5 \\
\hline 2015 & 0 & - & 6 & 95 & 6 \\
\hline 2016 & 1 & 50 & 3 & 40 & 4 \\
\hline Total & 7 & 48.4 & 96 & 70.0 & 103 \\
\hline
\end{tabular}


Table IV. AMNEs' acquisitions by group

\begin{tabular}{|c|c|c|c|c|c|}
\hline GROUP & $\begin{array}{l}\text { Acquisitions in } \\
\text { advanced host } \\
\text { countries }\end{array}$ & $\begin{array}{c}\% \\
\text { Average } \\
\text { acquired }\end{array}$ & $\begin{array}{l}\text { Acquisitions in } \\
\text { emerging host } \\
\text { countries }\end{array}$ & $\begin{array}{c}\% \\
\text { Average } \\
\text { acquired }\end{array}$ & $\begin{array}{c}\text { Total } \\
\text { number of } \\
\text { acquisitions }\end{array}$ \\
\hline Orange Group & 2 & 64.7 & 6 & 70.1 & 8 \\
\hline Telia Group & 3 & 100 & 4 & 48.5 & 7 \\
\hline Vodafone Group & 5 & 60.3 & 2 & 70 & 7 \\
\hline Singtel Group & 1 & 100 & 4 & 34.3 & 5 \\
\hline Telefónica Group & 2 & 100 & 3 & 83.5 & 5 \\
\hline $\begin{array}{l}\text { Wind Telecom Group } \\
\text { (Merged Q2 2011) }\end{array}$ & 2 & 81.4 & 2 & 24.1 & 4 \\
\hline Telenor Group & 2 & 55.9 & 2 & 60.2 & 4 \\
\hline Softbank Group & 4 & 94.7 & - & - & 4 \\
\hline $\begin{array}{l}\text { AINMT Group (Access } \\
\text { Industries Group) }\end{array}$ & 3 & 88.3 & - & - & 3 \\
\hline NTT DOCOMO Group & 2 & 13.5 & 1 & 30 & 3 \\
\hline Tele2 Group & 1 & 100 & 2 & 70.5 & 3 \\
\hline Telekom Austria Group & - & - & 3 & 73 & 3 \\
\hline $\begin{array}{l}\text { Trilogy International } \\
\text { Partners Group }\end{array}$ & 1 & 52 & 2 & 85.8 & 3 \\
\hline PHAROL Group & - & - & 2 & 28.8 & 2 \\
\hline Telekom Slovenije Group & - & - & 2 & 72.5 & 2 \\
\hline CK Hutchison Group & - & - & 1 & 29.8 & 1 \\
\hline NJJ Group & 1 & 100 & - & - & 1 \\
\hline Orange Belgium Group & 1 & 90 & - & - & 1 \\
\hline OTE Group & - & - & 1 & 13 & 1 \\
\hline Proximus Group & 1 & 100 & - & - & 1 \\
\hline TDC Group & 1 & 76.5 & - & - & 1 \\
\hline Telecom Italia Group & - & & 1 & 54.8 & 1 \\
\hline Telstra Group & 1 & 60 & - & - & 1 \\
\hline Vivendi Group & - & - & 1 & 26 & 1 \\
\hline Total & 33 & 74.2 & 39 & 56.4 & 77 \\
\hline
\end{tabular}


Table V. EMNEs' acquisitions by group

\begin{tabular}{|c|c|c|c|c|c|}
\hline GROUP & $\begin{array}{l}\text { Acquisitions in } \\
\text { advanced host } \\
\text { countries }\end{array}$ & $\begin{array}{c}\% \\
\text { average } \\
\text { acquired }\end{array}$ & $\begin{array}{l}\text { Acquisitions in } \\
\text { emerging host } \\
\text { countries }\end{array}$ & $\begin{array}{c}\% \\
\text { average } \\
\text { acquired }\end{array}$ & $\begin{array}{l}\text { Total number of } \\
\text { acquisitions }\end{array}$ \\
\hline Bharti Airtel Group & - & - & 12 & 88.75 & 12 \\
\hline Zain Group & - & - & 11 & 79.4 & 11 \\
\hline VimpelCom Group & 2 & 75 & 9 & 71.8 & 11 \\
\hline Etisalat Group & - & - & 9 & 51 & 9 \\
\hline $\begin{array}{l}\text { Global Telecom } \\
\text { Group }\end{array}$ & 1 & 13.7 & 7 & 68.6 & 8 \\
\hline $\begin{array}{l}\text { Maroc Telecom } \\
\text { Group }\end{array}$ & - & - & 8 & 84 & 8 \\
\hline MTN Group & 1 & 100 & 7 & 81.4 & 8 \\
\hline Axiata Group & 1 & 12.6 & 4 & 59.6 & 5 \\
\hline MTS Group & - & - & 5 & 90.8 & 5 \\
\hline $\begin{array}{l}\text { América Móvil } \\
\text { Group }\end{array}$ & - & - & 4 & 100 & 4 \\
\hline Oi Group & 1 & 100 & 3 & 24.8 & 4 \\
\hline $\begin{array}{l}\text { Emirates } \\
\text { International } \\
\text { Telecommunication }\end{array}$ & - & - & 3 & 38.2 & 3 \\
\hline Batelco Group & - & - & 2 & 58 & 2 \\
\hline Ooredoo Group & 1 & 12.3 & 1 & 40.8 & 2 \\
\hline Turkcell Group & - & - & 2 & 65.5 & 2 \\
\hline Abu Dhabi Group & - & - & 1 & 15 & 1 \\
\hline $\begin{array}{l}\text { Africell Group } \\
\text { (Lintel Group) }\end{array}$ & - & - & 1 & 95 & 1 \\
\hline Digicel Group & - & - & 1 & 100 & 1 \\
\hline $\begin{array}{l}\text { Maxis } \\
\text { Communications } \\
\text { Group (Binariang } \\
\text { Group) }\end{array}$ & - & - & 1 & 51 & 1 \\
\hline Megafone Group & - & - & 1 & 75 & 1 \\
\hline NMTC Group & - & - & 1 & 38 & 1 \\
\hline $\begin{array}{l}\text { Orascom Telecom } \\
\text { Media and } \\
\text { Technology Group }\end{array}$ & - & - & 1 & 34.7 & 1 \\
\hline STC Group & - & - & 1 & 51 & 1 \\
\hline $\begin{array}{l}\text { Telekom Srbija } \\
\text { Group }\end{array}$ & - & - & 1 & 65 & 1 \\
\hline Total & 7 & 48.4 & 96 & 70.0 & 103 \\
\hline
\end{tabular}


Table VI. Descriptive statistics ( $\mathrm{N}=175)$

\begin{tabular}{|c|c|c|c|c|}
\hline Variable & Mean & Std. Dev. & Min & Max \\
\hline Ownership & 66.7 & 32.8 & 0.1 & 100 \\
\hline Emerging country & 0.8 & 0.4 & 0 & 1 \\
\hline EMNES & 0.6 & 0.5 & 0 & 1 \\
\hline Subsidiary size & 4.3 & 8.7 & 0.01 & 51.0 \\
\hline Group international experience & 12.8 & 9.4 & 1 & 44 \\
\hline Host country concentration & 4408 & 1547 & 1485 & 10000 \\
\hline Home country concentration & 3974 & 1922 & 1453 & 10000 \\
\hline Host country size & 42.8 & 66.3 & 0.4 & 317.7 \\
\hline Home country size & 137.2 & 306.0 & 0.9 & 1335 \\
\hline Open markets & 56.3 & 16.2 & 13.3 & 90 \\
\hline Geographical distance & 3.8 & 2.9 & 0 & 17.0 \\
\hline$G_{\text {Geographical distance }}^{2}$ & 22.7 & 32.4 & 0 & 289 \\
\hline Cultural distance & 0.2 & 0.4 & 0 & 1 \\
\hline
\end{tabular}


Table VII. Correlations

\begin{tabular}{|c|c|c|c|c|c|c|c|c|c|c|c|c|c|}
\hline & (1) & (2) & (3) & (4) & (5) & (6) & (7) & (8) & (9) & (10) & (11) & (12) & (13) \\
\hline Ownership (1) & 1 & & & & & & & & & & & & \\
\hline Emerging country (2) & -0.05 & 1 & & & & & & & & & & & \\
\hline EMNEs (3) & 0.05 & $0.46^{*}$ & 1 & & & & & & & & & & \\
\hline Subsidiary size (4) & $-0.38 *$ & $-0.22 *$ & -0.03 & 1 & & & & & & & & & \\
\hline Group international experience (5) & 0.07 & -0.07 & $-0.22 *$ & 0.12 & 1 & & & & & & & & \\
\hline Host country concentration (6) & -0.01 & $0.29 *$ & 0.10 & $-0.30 *$ & -0.02 & 1 & & & & & & & \\
\hline Home country concentration (7) & $-0.15^{*}$ & $0.14^{*}$ & $0.28^{*}$ & -0.10 & $-0.19 *$ & 0.08 & 1 & & & & & & \\
\hline Host country size (8) & $-0.39 *$ & -0.01 & -0.04 & $0.52 *$ & -0.06 & $-0.30 *$ & -0.02 & 1 & & & & & \\
\hline Home country size (9) & 0.12 & $0.13^{*}$ & $0.24^{*}$ & 0.08 & 0.10 & -0.09 & $-0.42^{*}$ & 0.06 & 1 & & & & \\
\hline Open markets (10) & 0.06 & $-0.42^{*}$ & $-0.36 *$ & $0.16^{*}$ & 0.07 & $-0.16^{*}$ & -0.08 & $-0.13 *$ & $-0.12 *$ & 1 & & & \\
\hline Geographical distance (11) & -0.11 & $0.14^{*}$ & 0.12 & -0.03 & $0.21^{*}$ & 0.02 & 0.04 & 0.07 & $0.25 *$ & $-0.13^{*}$ & 1 & & \\
\hline Geographical distance $^{2}$ (12) & -0.11 & -0.05 & -0.03 & 0.02 & $0.18^{*}$ & -0.04 & -0.04 & 0.08 & $0.20^{*}$ & 0.06 & $0.91 *$ & 1 & \\
\hline Cultural distance (13) & 0.12 & -0.08 & -0.12 & -0.10 & -0.02 & 0.01 & $-0.21 *$ & $-0.20 *$ & -0.09 & 0.03 & $-0.14 *$ & -0.04 & 1 \\
\hline
\end{tabular}


Table VIII. Determinants of ownership acquired

\begin{tabular}{|c|c|c|c|c|c|}
\hline & Model 1 & Model 2 & Model 3 & Model 4 & Model 5 \\
\hline Emerging country & & $\begin{array}{l}-19.247^{*} \\
(10.576)\end{array}$ & & $\begin{array}{c}-23.257^{* *} \\
(10.759)\end{array}$ & $\begin{array}{c}-35.114^{* * *} \\
(11.635)\end{array}$ \\
\hline EMNES & & & $\begin{array}{c}8.726 \\
(8.001)\end{array}$ & $\begin{array}{l}13.074 \\
(8.154)\end{array}$ & $\begin{array}{l}-25.205 \\
(17.532)\end{array}$ \\
\hline Emerging country $*$ EMNEs & & & & & $\begin{array}{l}44.004^{* *} \\
(18.000)\end{array}$ \\
\hline Subsidiary size & $\begin{array}{c}-1.752^{* * *} \\
(0.572)\end{array}$ & $\begin{array}{c}-1.840^{* * *} \\
(0.573)\end{array}$ & $\begin{array}{c}-1.729^{* * *} \\
(0.567)\end{array}$ & $\begin{array}{c}-1.819^{* * *} \\
(0.565)\end{array}$ & $\begin{array}{c}-1.872^{* * *} \\
(0.552)\end{array}$ \\
\hline Group international experience & $\begin{array}{c}0.682^{*} \\
(0.352)\end{array}$ & $\begin{array}{l}0.671^{*} \\
(0.351)\end{array}$ & $\begin{array}{l}0.761^{* *} \\
(0.357)\end{array}$ & $\begin{array}{l}0.785^{* *} \\
(0.353)\end{array}$ & $\begin{array}{l}0.788^{* *} \\
(0.345)\end{array}$ \\
\hline Host country concentration & $\begin{array}{l}-0.003 \\
(0.002)\end{array}$ & $\begin{array}{l}-0.002 \\
(0.002)\end{array}$ & $\begin{array}{c}-0.003 \\
(0.002)\end{array}$ & $\begin{array}{c}-0.002 \\
(0.002)\end{array}$ & $\begin{array}{l}-0.002 \\
(0.002)\end{array}$ \\
\hline Home country concentration & $\begin{array}{c}-0.002 \\
(0.002)\end{array}$ & $\begin{array}{c}-0.001 \\
(0.002)\end{array}$ & $\begin{array}{l}-0.003 \\
(0.002)\end{array}$ & $\begin{array}{c}-0.002 \\
(0.002)\end{array}$ & $\begin{array}{l}-0.002 \\
(0.002)\end{array}$ \\
\hline Host country size & $\begin{array}{l}-0.103^{*} \\
(0.059)\end{array}$ & $\begin{array}{l}-0.099^{*} \\
(0.058)\end{array}$ & $\begin{array}{l}-0.104^{*} \\
(0.058)\end{array}$ & $\begin{array}{l}-0.100^{*} \\
(0.058)\end{array}$ & $\begin{array}{l}-0.103^{*} \\
(0.056)\end{array}$ \\
\hline Home country size & $\begin{array}{c}0.019 \\
(0.016)\end{array}$ & $\begin{array}{c}0.021 \\
(0.016)\end{array}$ & $\begin{array}{c}0.014 \\
(0.017)\end{array}$ & $\begin{array}{c}0.013 \\
(0.017)\end{array}$ & $\begin{array}{c}0.011 \\
(0.017)\end{array}$ \\
\hline Open markets & $\begin{array}{c}0.349 \\
(0.239)\end{array}$ & $\begin{array}{c}0.075 \\
(0.280)\end{array}$ & $\begin{array}{c}0.364 \\
(0.237)\end{array}$ & $\begin{array}{c}0.039 \\
(0.277)\end{array}$ & $\begin{array}{c}0.115 \\
(0.273)\end{array}$ \\
\hline Geographical distance & $\begin{array}{c}0.949 \\
(2.996)\end{array}$ & $\begin{array}{c}1.741 \\
(3.011)\end{array}$ & $\begin{array}{c}0.501 \\
(3.003)\end{array}$ & $\begin{array}{c}1.250 \\
(2.992)\end{array}$ & $\begin{array}{c}2.681 \\
(2.974)\end{array}$ \\
\hline Geographical distance ${ }^{2}$ & $\begin{array}{c}-0.312 \\
(0.253)\end{array}$ & $\begin{array}{c}-0.378 \\
(0.254)\end{array}$ & $\begin{array}{l}-0.273 \\
(0.254)\end{array}$ & $\begin{array}{l}-0.333 \\
(0.253)\end{array}$ & $\begin{array}{l}-0.428^{*} \\
(0.250)\end{array}$ \\
\hline Cultural distance & $\begin{array}{c}5.656 \\
(8.023)\end{array}$ & $\begin{array}{c}6.334 \\
(8.029)\end{array}$ & $\begin{array}{c}4.773 \\
(7.985)\end{array}$ & $\begin{array}{c}5.094 \\
(7.942)\end{array}$ & $\begin{array}{c}8.042 \\
(7.892)\end{array}$ \\
\hline $\begin{array}{l}\text { Dummy years } \\
\text { _cons }\end{array}$ & $\begin{array}{c}\text { Included*** } \\
29.645 \\
(29.525)\end{array}$ & $\begin{array}{c}\text { Included } * * * \\
50.405 \\
(31.406)\end{array}$ & $\begin{array}{c}\text { Included*** } \\
25.567 \\
(29.544)\end{array}$ & $\begin{array}{c}\text { Included }^{* * *} \\
48.535 \\
(31.008)\end{array}$ & $\begin{array}{c}\text { Included*** } \\
54.388^{*} \\
(30.337)\end{array}$ \\
\hline sigma & & & & & \\
\hline _cons & $\begin{array}{c}34.144^{* * *} \\
(2.457)\end{array}$ & $\begin{array}{c}33.891^{* * *} \\
(2.436)\end{array}$ & $\begin{array}{c}33.908^{* * *} \\
(2.442)\end{array}$ & $\begin{array}{c}33.482^{* * *} \\
(2.408)\end{array}$ & $\begin{array}{c}32.632^{* * *} \\
(2.345)\end{array}$ \\
\hline$N$ & 175 & 175 & 175 & 175 & 175 \\
\hline LL ratio test vs Model 1 & & $3.35 *$ & 1.18 & $5.89 *$ & $11.74^{* * *}$ \\
\hline LL ratio test vs Model 2 & & & & 2.54 & $8.39 * *$ \\
\hline LL ratio test vs Model 3 & & & & $4.71^{* *}$ & $10.56 * * *$ \\
\hline$L L$ ratio test vs Model 4 & & & & & $5.85 * *$ \\
\hline
\end{tabular}




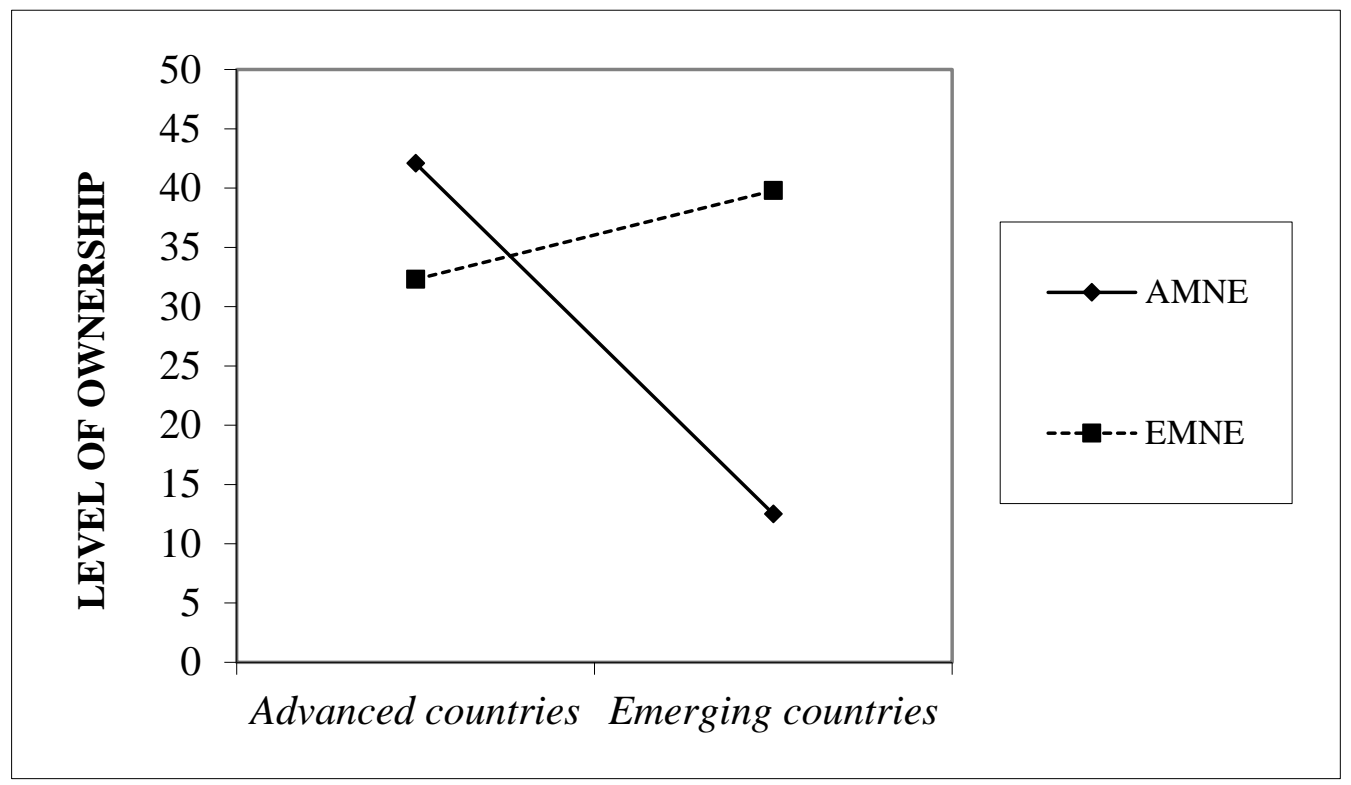

Figure I. Interaction between emerging countries and EMNEs 
APPENDIX A. Host and Home Countries Included

\begin{tabular}{|c|c|c|c|c|}
\hline \multicolumn{5}{|c|}{ Host countries (81 countries) } \\
\hline Angola & Congo & Ireland & New Zealand & Tunisia \\
\hline Armenia & Congo, Dem. Rep & Italy & Niger & Turkey \\
\hline Australia & Cote d'Ivoire & Japan & Nigeria & Turkmenistan \\
\hline Bangladesh & Cyprus & Jordan & Norway & Uganda \\
\hline Belarus & Denmark & Kazakhstan & Pakistan & Ukraine \\
\hline Benin & Egypt & Kenya & Paraguay & United Arab Emirates \\
\hline Bolivia & Equatorial Guinea & Korea, South & Peru & United Kingdom \\
\hline Bosnia & Estonia & Kyrgyzstan & Portugal & USA \\
\hline Botswana & Gabon & Laos & Saudi Arabia & Uruguay \\
\hline Bulgaria & Greece & Luxembourg & Singapore & Uzbekistan \\
\hline Burkina Faso & Guinea-Bissau & Macedonia & Slovenia & Venezuela \\
\hline Burundi & Guyana & Malta & Spain & Yemen \\
\hline Cabo Verde & Haiti & Moldova & Sri Lanka & Zambia \\
\hline Central Africa & Honduras & Morocco & Sweden & \\
\hline Chad & Hong Kong & Namibia & Switzerland & \\
\hline Chile & Indonesia & Nepal & Tajikistan & \\
\hline Colombia & Iran & Netherlands & Togo & \\
\hline
\end{tabular}

Home country group (35 countries)

\begin{tabular}{|c|c|c|c|c|}
\hline Australia & France & Japan & Portugal & South Africa \\
\hline Austria & Gambia & Kuwait & Qatar & Spain \\
\hline Bahrein & Greece & Luxemburg & Russian Federation & Sweden \\
\hline Belgium & Hong Kong & Malaysia & Saudi Arabia & Turkey \\
\hline Brazil & India & Mexico & Serbia & United Arab Emirates \\
\hline Denmark & Italy & Morocco & Singapore & United Kingdom \\
\hline Egypt & Jamaica & Norway & Slovenia & USA \\
\hline
\end{tabular}

